3 マイクロフォン系による 3 次元音源定位と音声分離 一理論的考察とシミュレーション*

岡田修 - ${ }^{* *}$ ・佐藤史 尚 ${ }^{* *}$ ・森田龍 彌 ${ }^{* *}$

\title{
3-Dimensional Sound Localization and Voice Separation by 3-Microphone System -Theoretical Study and Simulation*
}

\author{
Shuuichi OKadA**, Fumitaka SAto** and Tatsuya Morita**
}

The auditory system has flexible functions of voice recognition in noisy environment. This ability should be due to not only the linguistic function but also binaural sound localization.

Sound localization and voice separation based on fundamental 2-dimensional acoustical field model has been proposed formerly. However, the problem becomes more complicated according to increase of speakers.

In this paper, more realistic problem of 3 -dimensional sound localization and voice separation is discussed theoretically.

Validity of the algorithm for solving the problem is comfirmed by simulation analysis. That is, mixed voices of three persons which would be detected by the microphones are synthesized using voice data base. Then, the individual voice is separated after estimating presetting speaker locations on the basis of the algorithm.

Satisfactory results are obtained in this simulation analysis.

\section{1.まえがき}

われわれ人間にとって視覚機能は, 最む重要な感覚機 能である. しかし，視覚機能の及ふ範囲は比較的限られ た領域であるため，体軀，頭部あるいは眼球を動かして， 対象物に視野に合わせる必要がある。聴覚機能は，乙の ような視覚機能の補助，あるいは発現の前段階として, 重要な役割を果たしている．また，われわれの聴覚は， パーティ会場のような騒音中であ話者の言葉を聞き取る ことができる機能をむっている．乙の聴覚系の優れた聴 取能力には，言語中枢における会話の理解力が働いてい ると考えられるが，両耳による音源定位機能も重要な働 きをしていると考えられる.

一方, 情報処理システムやロボットは, 人間の代行装 置として開発され，人間のあつ優れた機能に接近すべく 研究されてきた. すなわち, 視覚機能の及ばない周辺領

* 原稿受付 1992. 5. 20

** 大阪大学 工学部 Faculty of Engineering, Osaka University; Yamadaoka 2, Suita-city, Osaka 565, JAPAN

Key Words : sound localization, voice separation, acoustical field model, voice processing, parameter estimation for acoustical field.
域から発生するさまざまな音の位置関係を把握し，選択 する聴覚の環境適応性は, 情報処理システムやロボット によってあ重要な機能であるといえる.

てのような音源定位と複数話者の音声分離のアルゴリ ズムについては, 従来音場モデルに基づく方法など, す でにいくつか論文が発表されているい). しかし，従来 は音源位置が既知となっている状況での音声分離が扱わ れていた. そてで，筆者らは先に音声のスペクトルの差 異に着目して音源位置を推定し，その位置情報を用いて 音声を分離する方法を提案し，音声分離の可能条件およ び精度について報告した ${ }^{5) \sim 7}$.

本研究では, 従来の 2 マイクロフォンによる平面上の 音源定位を，3マイクロフォンによるより現実的な3次 元空間の音源定位に拡張し， 3 話者の音声分離について シミュレーションによって検討する.

\section{2. 音声分離法}

\section{1 音声分離の基本手順}

音声分離は次の 3 段階を実行するてとによって遂行さ れるあのである.

（1）音場モデルに基づき, 複数のマイクで採取した音 
声（マイク音）より，音源位置に関するパラメー 夕を推定する，すなわち，音源定位を行う5),6).

（2）マイク音に音場モデルより求めた逆伝達関数を掛 けることにより，音声を分離する ${ }^{5,6)}$.

（3）自由音場を仮定した上記の分離法では，現実の環 境においては䛊差を生じるてとは避けられない。 そこで分離音声の評価を行い, 推定誤差を減少さ せるようにパラメータを修正するフィードバック が (1)，(2) の補助として必要である ${ }^{6), 7)}$.

以上の各段階における基本的な問題点については, 従 来の 2 マイクロフォンによる 2 次元空間音声分離におい て検討した。

本論文では，3 次元空間における上記 (1)，(2) の問題 に主眼において述べる.

\section{2 音声分離の原理}

自由音場において, 点音源 $j(=0,1,2, \cdots, m-1)$ か ら発生した信号 $u_{j}(t)$ をマイク $i(=0,1,2, \cdots, n-1)$ で検出する場合, マイクに入力される音圧 $v_{i}(t)$ は, 周 波数領域において，連立方程式

$$
\begin{aligned}
& V(\omega)=G(\omega) U(\omega) \\
& G_{i j}=\left(\frac{K}{\tau_{i j}}\right) \exp \left(-j \omega \tau_{i j}\right)
\end{aligned}
$$

によって表わすてとができる ${ }^{3), 4)}$. こてで, $V(\omega), U(\omega)$ はそれぞれ $v_{i}(t), u_{j}(t)$ のフーリエ変換を要素とする綐 ベクトル, $G(\omega)$ は音場の伝達特性を表わす行列で, $G_{i j}$ はその要素である. また, $\tau_{i j}$ は音波が音源 $j$ からマイ ク $i$ に達するまでの時間 $[\mathrm{msec}]$ であるが, 距離の単位 として, 1 [msec] の間に音が伝搬する距離 $[0.34 \mathrm{~m}]$ を 用いれば, 音源とマイク間の距離と見てあ差し支えない. なお， $K$ は上記の時間一距離の変換係数, マイクの増 幅率などを含めた係数である.したがって，音源数 $m$ とマイク数 $n$ が等しく, $\operatorname{det} G \neq 0$ であれば,

$$
U(\omega)=G(\omega)^{-1} V(\omega)
$$

と表現できる.ここで $V$ はマイクで検出した音で既知 であるから, 音場特性 $G$ が既知, すなわち音源位置に 対応するパラメータ $\tau_{i j}$ が推定できれば, 音源信号を分 離することができる.

\section{3 次元空間音源定位}

\section{1 幾何学的考察}

ここでは最も基本的な場合として, Fig.1 (a) に示す ように, 3 次元空間座標をとり，乙の空間にある三つの 音源信号 $u_{0}(t), u_{1}(t), u_{2}(t)$ を, Fig. 1 (b) に示す半 径 $r$ の円に内接する正三角形（辺長を $2 a, r^{2}=a^{2}+b^{2}$ とする）の頂点に配置された 3 個のマイク,

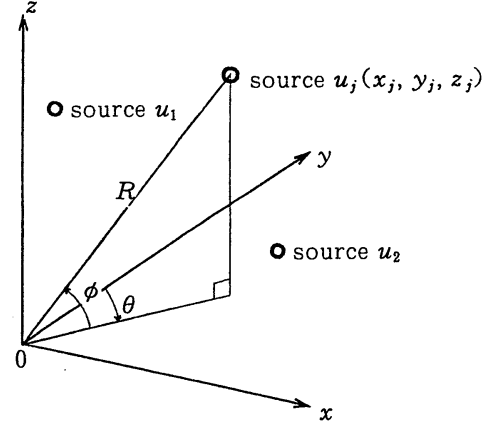

(a) Coordinate for the sound location

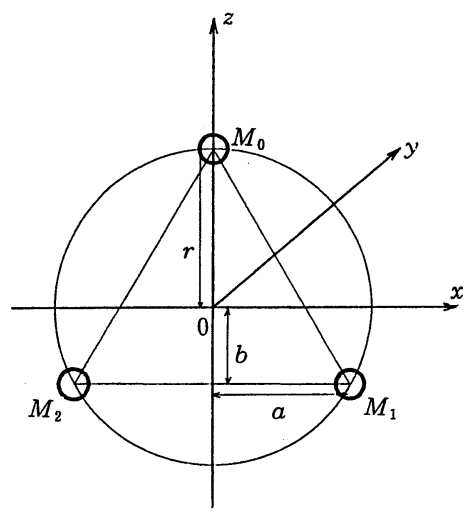

(b) Arrangement of three microphones

Fig. 1 Situation of sound localization

$$
\begin{aligned}
& M_{0}=(0,0,2 b), M_{1}=(a, 0,-b), \\
& M_{2}=(-a, 0,-b)
\end{aligned}
$$

で検出する場合を想定する.

音源 $j$ の位置 $\left(x_{j}, y_{j}, z_{j}\right)$ に対する原点からの距離, 方位角, 仰角を $\left(R_{j}, \theta_{j}, \phi_{j}\right)$ とすれば,

$$
\begin{gathered}
x_{j}=\frac{R_{j} \tan \theta_{j}}{h_{j}}, y_{j}=\frac{R_{j}}{h_{j}}, z_{j}=\frac{R_{j} \tan \phi_{j}}{h_{j}} \\
h_{j}=\sqrt{\left(1+\tan ^{2} \theta_{j}+\tan ^{2} \phi_{j}\right)} \\
\tan \phi_{j}=\frac{\tan \phi_{j}}{\cos \theta_{j}}
\end{gathered}
$$

となる. また, 音源 $j$ から各マイクまでの距離（音の伝 達時間) は

$$
\begin{gathered}
\tau_{0 j}=\sqrt{{R_{j}{ }^{2}+r^{2}-4 b z_{j}}^{2}} \\
\tau_{1 j}=\sqrt{{R_{j}{ }^{2}+r^{2}-2 a x_{j}+2 b z_{j}}^{2}}=\sqrt{{R_{j}{ }^{2}+r^{2}+2 a x_{j}+2 b z_{j}}^{2}} \\
b=\frac{r}{2}, r^{2}=a^{2}+b^{2}
\end{gathered}
$$

となる.したがって, マイク音より $\tau_{0 j}, \tau_{1 j}, \tau_{2 j}$ が推定 
できれば, 音源位置は

$$
\begin{gathered}
R_{j}=\sqrt{\frac{\tau_{0 j}{ }^{2}+\tau_{1 j}{ }^{2}+\tau_{2 j}{ }^{2}}{3-r^{2}}} \\
\tan \theta_{j}= \pm \frac{Q}{\sqrt{P^{2} Q^{2}-P^{2}-Q^{2}}} \\
\tan \phi_{j}= \pm \frac{P \cos \theta}{\sqrt{P^{2} Q^{2}-P^{2}-Q^{2}}}, \\
P=\frac{2 \sqrt{3} r R_{j}}{\tau_{2 j}{ }^{2}-\tau_{1 j}{ }^{2}} \\
Q=\frac{6 r R_{j}}{\left(\tau_{1 j}{ }^{2}-\tau_{0 j}{ }^{2}\right)+\left(\tau_{2 j}{ }^{2}-\tau_{0 j}{ }^{2}\right)}
\end{gathered}
$$

と求めるととができる.

なお，音源までの距離 $R$ がマイク間隔 $2 a$ に比べて 充分大きい場合には，(4) 式より

$$
\begin{aligned}
& \tau_{R 0 j}=\tau_{0 j}-R_{j}=-\frac{2 b \tan \phi_{j}}{h_{j}} \\
& \tau_{R 1 j}=\tau_{1 j}-R_{j}=-\frac{a \tan \theta_{j}-b \tan \phi_{j}}{h_{j}} \\
& \tau_{R 2 j}=\tau_{2 j}-R_{j}=\frac{a \tan \theta_{j}+b \tan \phi_{j}}{h_{j}}
\end{aligned}
$$

と近似するてとができ, マイクまでの距離の差

$$
\begin{aligned}
& \Delta \tau_{1 j}=\tau_{0 j}-\tau_{1 j}=\tau_{R 0 j}-\tau_{R 1 j} \\
& \Delta \tau_{2 j}=\tau_{0 j}-\tau_{2 j}=\tau_{R 0 j}-\tau_{R 2 j}
\end{aligned}
$$

を用いて

$$
\begin{aligned}
\tan \theta_{j}= \pm \frac{\tau_{b}}{\sqrt{4 a^{2}-\tau_{a}{ }^{2}-\tau_{b}{ }^{2}}} & \\
\tan \phi_{j}= \pm \frac{\tau_{a} \cos \theta}{\sqrt{4 a^{2}-\tau_{a}{ }^{2}-\tau_{b}^{2}}} & , \\
\tau_{a} & =\frac{\Delta \tau_{1 j}+\Delta \tau_{2 j}}{\sqrt{3}} \\
\tau_{b} & =\Delta \tau_{1 j}-\Delta \tau_{2 j}
\end{aligned}
$$

と近似することができる. すなわち, 伝達時間差 $\Delta \tau_{1 j}$, $\Delta \tau_{2 j}$ は方位角, 仰角を推定するための重要なパラメー タであるてとが分かる. また，(6) 式により距離 $R_{j}$ は 消去されているてとが分かる.

\section{2 伝達時間の推定法}

3 人の話者が同一のスペクトルパターンをあつ音声を 発声する確率は低いと考えられる．したがって，各時刻 に怙けるスペクトル $U_{0}, U_{1}, U_{2}$ につて，いずれかの パワ $U_{j}$ がほかの二つのパワより十分大きいような周 波数（たとえばホルマント）が存在すると考えられる. いま, このような周波数 $\omega=2 \pi f$ に着目すれば, 三つ
のマイクに入射する音 $V_{0}, V_{1}, V_{2}$ はそれぞれ

$$
\begin{aligned}
& V_{0}(\omega)=\left(\frac{K}{\tau_{0 j}}\right) U_{j}(\omega) \exp \left(-j \Phi_{0}\right) \\
& V_{1}(\omega)=\left(\frac{K}{\tau_{1 j}}\right) U_{j}(\omega) \exp \left(-j \Phi_{1}\right) \\
& V_{2}(\omega)=\left(\frac{K}{\tau_{2 j}}\right) U_{j}(\omega) \exp \left(-j \Phi_{2}\right)
\end{aligned}
$$

と近似できる. ただし実際の処理に扔いては，どの音源 であるか，乙の時点では分からない．

（8）式に扔いて，たとえば $V_{0}$ を基準として，位相差 之振幅比よりそれぞれ，伝搬時間の差と比

$$
\begin{aligned}
& \Delta \tau_{1 j}=\frac{\Phi_{0}-\Phi_{1}}{\omega}+\frac{n}{f} \\
& \Delta \tau_{1 j}=\tau_{0 j}-\tau_{1 j}, \quad \rho_{1 j}=\frac{\tau_{0 j}}{\tau_{1 j}} \\
& \Delta \tau_{2 j}=\frac{\Phi_{0}-\Phi_{2}}{\omega}+\frac{n}{f} \\
& \Delta \tau_{2 j}=\tau_{0 j}-\tau_{2 j}, \quad \rho_{2 j}=\frac{\tau_{0 j}}{\tau_{2 j}}
\end{aligned}
$$

を求める. 乙てで, $\left(\Delta \tau_{i j}, \rho_{i j}\right), i=1,2$ は, 音源位置 に対応したパラメータである. $\Delta \tau_{i j}$ は不定項 $n / f$ のと り方で一意に決めるてとができないが, $n$ は条件

$$
\begin{aligned}
& \left|\Delta \tau_{i j}\right|<2 a \\
& \left(\rho_{i j}-1\right) \Delta \tau_{i j}>0
\end{aligned}
$$

を満たすように選ばなければならない.いま分析周波数 の上限を $f_{m}$ とすれば, (10) 式を満たす不定値 $n$ は

$$
|n|<4 a f_{m}
$$

を満たす数だけ存在し $\left((9)\right.$ 式で $n>0,\left(\Phi_{0}-\Phi_{1}\right) / \omega=$ $-2 a$ または, $n<0,\left(\Phi_{0}-\Phi_{1}\right) / \omega=2 a$ とおく), 乙の 内のただ一つが音源 $j$ に対応するあのである. すなわち 分析周波数帯域は, 音声帯域を包含するてとが望ましい が, マイク間隔 $2 a$ を固定したままで, 高周波数域まで 広げると, 偽の $\Delta \tau_{i j}$ が増加するという問題がある. 乙 の条件は 2 マイクによる 2 次元音源定位であ考慮された あのである.

一方, 3 次元音源定位では $(9 a),(9 b)$ 式より, 二組 の $\tau_{0 j}$ がそれぞれ

$$
\begin{aligned}
\tau_{0 j} & =\frac{\rho_{1 j} \Delta \tau_{1 j}}{\rho_{1 j}-1} \\
\tau_{0 j} & =\frac{\rho_{2 j} \Delta \tau_{2 j}}{\rho_{2 j}-1}
\end{aligned}
$$

之求められる. 乙の二つの值は本来等しいはずであるが, （8）式が近似式であるてとと，音環境のさまざまな不確 定性のため, 現実には等しくならない.

そこで，てれらの $\tau_{0 j}$ がともに（10）式の条件を満た すとき, この対から得られる $\tau_{0 j}$ の平均値を, $\tau_{0 j}$ の推定 
值とする. いまてれを $\tau_{0 j}{ }^{*}$ と表わすと, $\tau_{0 j}{ }^{*}$ は $\tau_{0 j}$ とは 異なる值である. したがって, $\tau_{0 j}{ }^{*}$ を( $\left.9 \mathrm{a}\right),(9 \mathrm{~b})$ 式の $\tau_{0 j}$ として用いると, $\Delta \tau_{1 j}, \Delta \tau_{2 j}$ の値が変わってしまう. 3.1 で述べたように, $\Delta \tau_{1 j}, \Delta \tau_{2 j}$ は音源の方位を決める 重要なパラメータであり, この值が変わることは都合が 悪い. そこで $\Delta \tau_{1 j}, \Delta \tau_{2 j}$ の值が変わらないように $\tau_{1 j}$, $\tau_{2 j}$ の值を

$$
\begin{aligned}
& \tau_{1 j}{ }^{*}=\tau_{0 j}{ }^{*}-\Delta \tau_{1 j} \\
& \tau_{2 j}{ }^{*}=\tau_{0 j}{ }^{*}-\Delta \tau_{2 j}
\end{aligned}
$$

之補正する必要がある. 以上の補正は 2 次元音源定位で は考慮する必要がなかった処理である.

\section{3 統計的処理}

以上が音源定位法の概要であるが, 現実の音声分離で は下記のような問題に対処するための統計的処理が必要 になる.

（1）推定の基礎となる（8）式は近似式である.

（2）（10）式の条件を満す不定值 $n$ のうち, 正しいもの を選び出す必要がある.

（3）いま処理の対象となっているデータがどの音源に 由来するあのであるか識別する必要がある.

そてで，3.2で述べたような周波数分析を各時刻につ いて行い，各周波数について (11) 式を満たすすべての $\Delta \tau_{1 j}, \Delta \tau_{2 j}$ に関するヒストグラムを作る. ヒストグラム にはそれぞれ 3 音源に対応する極大点が現れると期待さ れる (Fig. 2 参照). 乙の極大点を值の大きいむのから 三つ選出し，乙れらの極大点に仮番号を与える. 次にそ の後のマイク音から得られる $\Delta \tau_{1 j}, \Delta \tau_{2 j}$, あるいはヒス トグラムに用いた個々の $\Delta \tau_{1 j}, \Delta \tau_{2 j}$ を用いて, (11) 式 を満たす範囲で $n$ の值を変えながら, 三つの極大点の いずれに最も近いかを調へ，その番号をこの $\Delta \tau_{1 j}, \Delta \tau_{2 j}$ に対応する音源であると識別する.

以上の手順により，個々の $\Delta \tau_{1 j}, \Delta \tau_{2 j}$ が 3 音源に対 応する三つのグループに分類されれば，グループごとに $\Delta \tau_{1 j}, \Delta \tau_{2 j}$ および付随する $\rho_{1 j}, \rho_{2 j}$ のヒストグラムを作 り，その極大值を与える $\left(\Delta \tau_{1 j}, \rho_{i j}\right)$ から (5) 式を用い て, 音源の位置 (距離, 方位角, 仰角) を推定する (Fig. 3 参照).

\section{4. 音声分離}

音源位置が推定できれば,（2）式を用いて音声分離を 行うことができるが，乙こで注意すべき問題点がいくつ かある。

音源が三つ以上ある場合，上記の $\Delta \tau_{1 j}, \Delta \tau_{2 j}$ に関す るヒストグラムには，理論上，音源に対応する数の極大 点が現れ，その極大点に基づいて音源位置を推定するて
とができる.すなわち, 複数音源について音源定位は可 能である.しかし，(2) 式よりわかるように，マイクの 個数以上の音声を分離することは困難である. 一般化逆 行列を用いて代表解を求める方法は考えられるが, 正し く音声分離が行える保証はない. すなわち, 音源定位之 音声分離は異なった次元の問題である.

音声分離の処理では（2）式に示すように，音場伝達関 数の行列式を右辺分母として使用する必要があるが， 3 次元音声分離ではこの分母が不安定根をもつ場合が多い. 理論的には，乙の不安定根を持つ因数と等しい因数が分 子にあ現れ，両者が相殺して不安定根が消去される. し かし，現実の音源定位では誤差があるため，不安定根が 消去されないで残ってしまうのである. そてで，制御シ ステムの安定化の手法として知られている, 不安定極の 再配置法を適用して安定化を行った. すなわち分母につ いて因数分解実行し，不安定根（複素平面上の単位円外 に位置するもの）があれば，偏角は不変のままで絶対值 を減少させることにより，安定領域（単位円内）に移動 したのち, 因数を展開して分母を再合成する方法である. なお，不安定因数を単純に除去する（1亿置き換える） 之, 分子の次数より分母の次数が低くなる場合があり都 合が悪い.

また，(2) 式において伝達関数行列の要素は， $Z$ 変換 では

$$
G_{i j}=\frac{K}{\tau_{i j}} Z^{-T_{i j}}
$$

と表わされる. こてで $T_{i j}$ は $\tau_{i j}$ をサンプル周期で量子 化した值である.（2）式の逆行列の各要素は，乙の $G_{i j}$ の積の和と差より成り, $G_{i j}$ の積は係数の積とむだ時間 $\tau_{i j}$ の和で表わされる.むだ時間は，データの移動で実 現できる.ただし，時間は量子化されているため，小数 部eについては

$$
Z^{-e}=\left[(1-e)+e \times Z^{-1}\right]
$$

のように補間をとる必要がある. 現実には前後数サンプ ルの值から高次の補間をとる.

\section{5. シミュレーション}

以上の 3 次元音源定位法の動作確認のために, シミュ レーションを行った. まず，音源位置を設定し，3人の 音声がそれぞれの音源位置で発声された場合を想定して, 音声データベースの個人音声より，マイクで採取される 音声を (1) 式を用いて合成する. このマイク音から上記 の手法で正しく音源位置が推定できるかどうかを確かめ た。なお，処理のパラメータには下記の值を用いた。

音声データのサンプリング周波数 $8[\mathrm{kHz}]$ 


\section{音声長さ}

マイク間隔

分析周波数帯域

位置設定条件

$$
1[\mathrm{sec}]
$$

$0.17[\mathrm{~m}]$

$0.125 \sim 3.0[\mathrm{kHz}]$

8 種類 (Table 1 参照)

処理の経過例を Fig. 2, Fig. 3 に示す. Fig. 2 は音源 位置を Table 1 の 1 のように設定した場合の $\Delta \tau_{1}, \Delta \tau_{2}$ のヒストグラムを微分フィルタによって極大点検出した あのである. それぞれ三つの極大点が現れており，三つ の音源に対応すると考えられる. つぎにてれら $\Delta \tau_{1}, \Delta \tau_{2}$ に関する極大点に対応関係を付け，それぞれの極大点 の近傍のデータについて距離, 方位角，仰角を計算し， ヒストグラムをとる.Fig. 3 は第 2 音についてのヒス トグラムを微分フィルタで極值検出したあので, 距離は $1.08 \mathrm{~m}$, 方位角 $-45 \mathrm{deg}$, 仰角 $30 \mathrm{deg}$ が音源位置であ ると判定できる.

同様の処理を 8 種類の位置設定条件について行い, Table 1 亿示す結果を得た. 距離の推定については誤 差が大きいが, 方位角, 仰角は平均誤差 $0.55 \mathrm{deg}$. で求 められており，正しく推定できたといえる.

距離の推定誤差が大きい理由は，(8) 式のように 3 音の 混合したマイク音を単独音と近似しているとてろにある. また, 音源推定には本質的に，(6) 式のように距離 $R_{j}$ が 消去され，各 $\tau_{i j}$ は $R_{j}$ を不定項とする $\tau_{i j}=\tau_{R i j}+R_{j}$

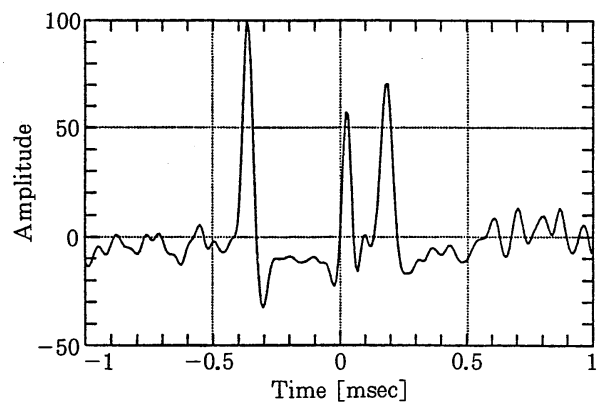

(a) On the case of $\Delta \tau_{1}$

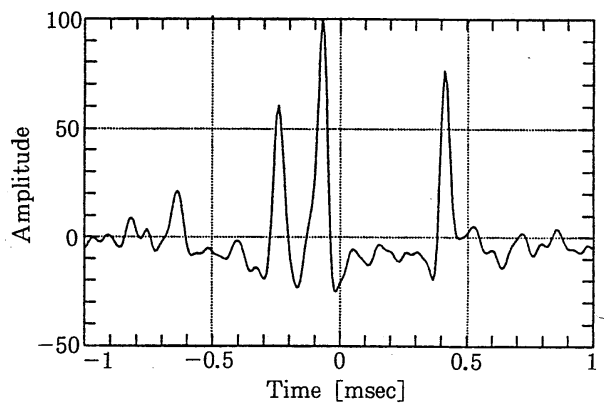

(b) On the case of $\Delta \tau_{2}$

Fig. 2 An example of peak detected histogram by a differential filter
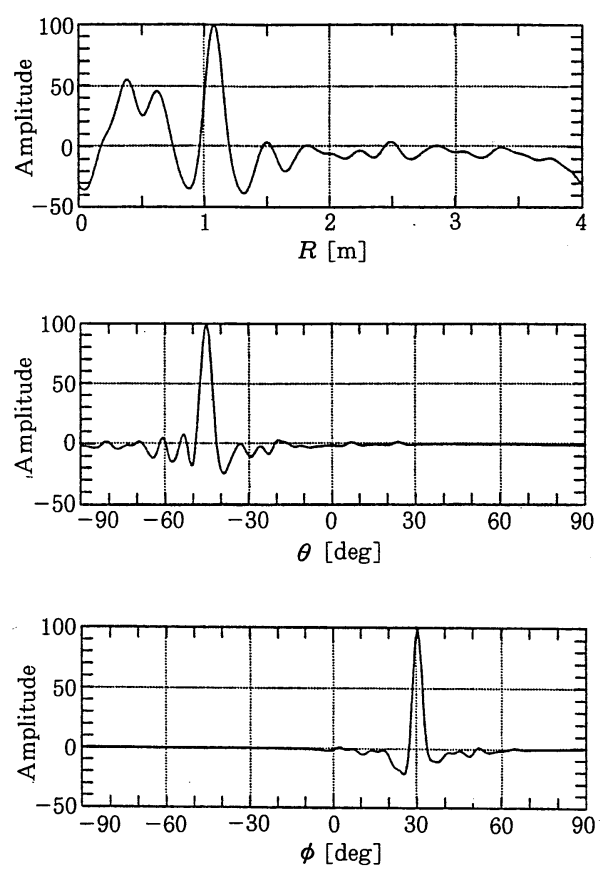

Fig. 3 An example of peak detected histogram on sound location $(R, \theta, \phi)$ by a differential filter

Table 1 Result of simulation on sound localization

\begin{tabular}{|c|c|c|c|c|c|c|c|}
\hline \multirow{2}{*}{$\begin{array}{l}\text { Test } \\
\text { No. }\end{array}$} & \multirow{2}{*}{$\begin{array}{l}\text { Source } \\
\text { No. }\end{array}$} & \multicolumn{3}{|c|}{ Source location } & \multicolumn{3}{|c|}{ Estimated location } \\
\hline & & $R$ & $\theta$ & $\phi$ & $R$ & $\theta$ & $\phi$ \\
\hline 1 & $\begin{array}{l}1 \\
2 \\
3\end{array}$ & $\begin{array}{l}1 \\
1 \\
1\end{array}$ & $\begin{array}{r}-60 \\
-45 \\
60\end{array}$ & $\begin{array}{r}-30 \\
30 \\
5\end{array}$ & $\begin{array}{l}0.23 \\
1.08 \\
0.89\end{array}$ & $\begin{array}{c}-58.36 \\
-45.0 \\
59.77\end{array}$ & $\begin{array}{r}-30.23 \\
30.23 \\
4.21\end{array}$ \\
\hline 2 & $\begin{array}{l}1 \\
2 \\
3\end{array}$ & $\begin{array}{l}1 \\
1 \\
1\end{array}$ & $\begin{array}{r}0 \\
30 \\
-45\end{array}$ & $\begin{array}{r}0 \\
30 \\
-15\end{array}$ & $\begin{array}{l}0.17 \\
0.89 \\
0.22\end{array}$ & $\begin{array}{c}-0.70 \\
30.23 \\
-45.0\end{array}$ & $\begin{array}{r}-0.70 \\
30.23 \\
-14.77\end{array}$ \\
\hline 3 & $\begin{array}{l}1 \\
2 \\
3\end{array}$ & $\begin{array}{l}1 \\
1 \\
1\end{array}$ & $\begin{array}{r}-30 \\
-30 \\
60\end{array}$ & $\begin{array}{r}15 \\
-15 \\
0\end{array}$ & $\begin{array}{l}0.23 \\
0.16 \\
0.83\end{array}$ & $\begin{array}{r}-31.64 \\
-30.23 \\
59.77\end{array}$ & $\begin{array}{r}14.77 \\
-14.77 \\
0.70\end{array}$ \\
\hline 4 & $\begin{array}{l}1 \\
2 \\
3\end{array}$ & $\begin{array}{l}1 \\
1 \\
1\end{array}$ & $\begin{array}{r}45 \\
-45 \\
0\end{array}$ & $\begin{array}{r}30 \\
30 \\
-60\end{array}$ & $\begin{array}{l}0.30 \\
0.33 \\
0.89\end{array}$ & $\begin{array}{r}45.00 \\
-43.59 \\
-0.70\end{array}$ & $\begin{array}{r}30.23 \\
30.23 \\
-60.47\end{array}$ \\
\hline 5 & $\begin{array}{l}1 \\
2 \\
3\end{array}$ & $\begin{array}{l}1 \\
1 \\
1\end{array}$ & $\begin{array}{r}45 \\
5 \\
-45\end{array}$ & $\begin{array}{r}-30 \\
45 \\
-15\end{array}$ & $\begin{array}{l}0.48 \\
0.88 \\
0.16\end{array}$ & $\begin{array}{r}45.0 \\
4.92 \\
-44.30\end{array}$ & $\begin{array}{c}-30.23 \\
45.0 \\
-14.06\end{array}$ \\
\hline 6 & $\begin{array}{l}1 \\
2 \\
3\end{array}$ & $\begin{array}{l}1 \\
1 \\
1\end{array}$ & $\begin{array}{r}30 \\
-15 \\
-45\end{array}$ & $\begin{array}{r}15 \\
30 \\
-45\end{array}$ & $\begin{array}{l}0.22 \\
1.05 \\
0.75\end{array}$ & $\begin{array}{r}33.05 \\
-15.47 \\
-45.00\end{array}$ & $\begin{array}{r}16.17 \\
30.23 \\
-44.30\end{array}$ \\
\hline 7 & $\begin{array}{l}1 \\
2 \\
3\end{array}$ & $\begin{array}{l}1 \\
1 \\
1\end{array}$ & $\begin{array}{r}-5 \\
5 \\
5\end{array}$ & $\begin{array}{r}30 \\
5 \\
-30\end{array}$ & $\begin{array}{l}1.02 \\
0.13 \\
0.53\end{array}$ & $\begin{array}{r}-4.92 \\
4.92 \\
4.92\end{array}$ & $\begin{array}{r}30.23 \\
5.63 \\
-29.53\end{array}$ \\
\hline 8 & $\begin{array}{l}1 \\
2 \\
3\end{array}$ & $\begin{array}{l}1 \\
1 \\
1\end{array}$ & $\begin{array}{r}-30 \\
-30 \\
60\end{array}$ & $\begin{array}{r}15 \\
-15 \\
0\end{array}$ & $\begin{array}{l}0.16 \\
0.19 \\
0.88\end{array}$ & $\begin{array}{r}-31.64 \\
-30.23 \\
61.17\end{array}$ & $\begin{array}{r}18.28 \\
-14.77 \\
0.00\end{array}$ \\
\hline
\end{tabular}




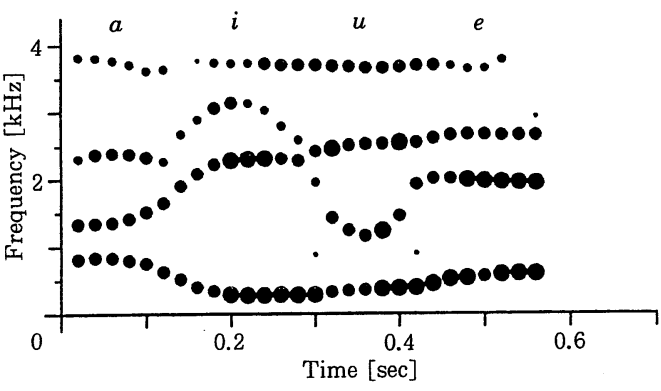

(a) Formant patterns of source 1

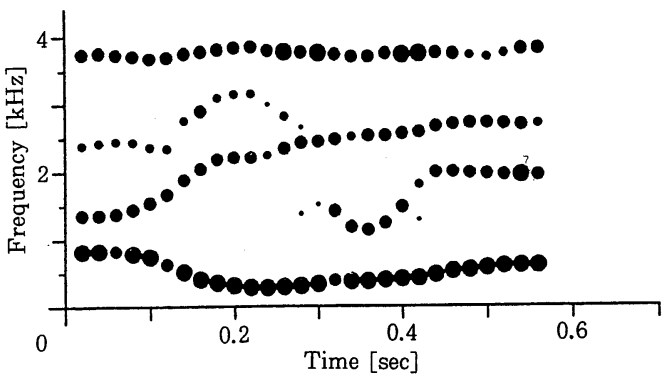

(b) Formant patterns of the separated voice

Fig. 4 An example of voice separation

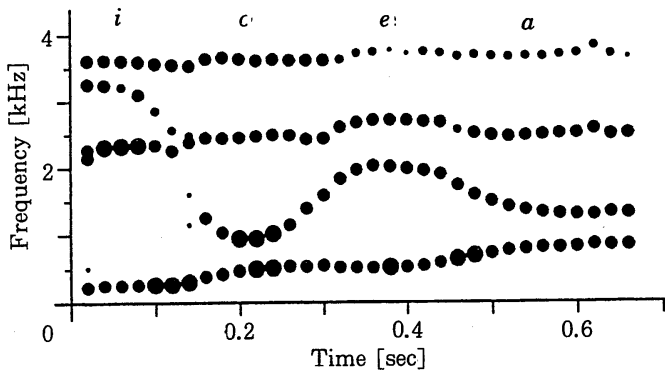

(a) Formant patterns of source 2

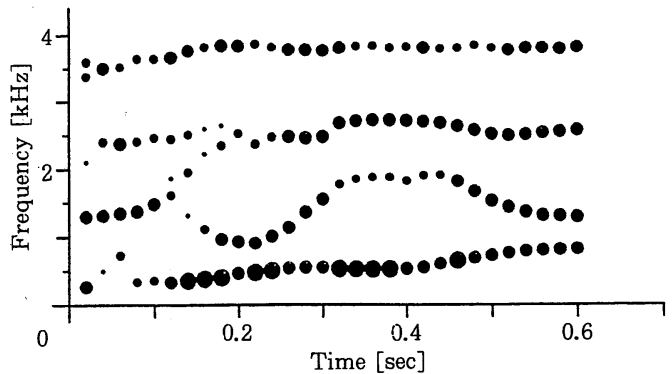

(b) Formant patterns of the separated voice

Fig. 5 An example of voice separation

として求められる傾向があることに起因する.

Table 1 のデータについて, 音声分離を行った. その 一例として試行番号 1 についての音声ホルマントパター

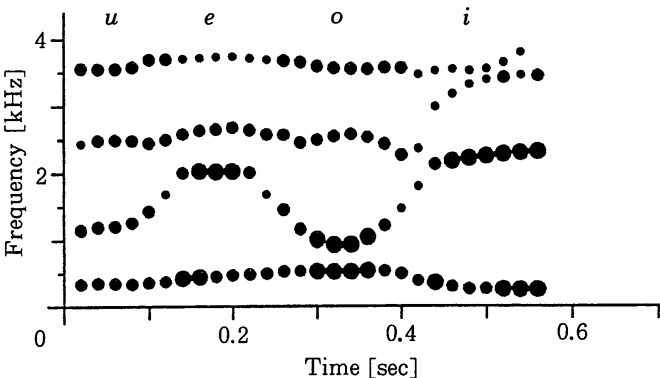

(a) Formant patterns of source 3

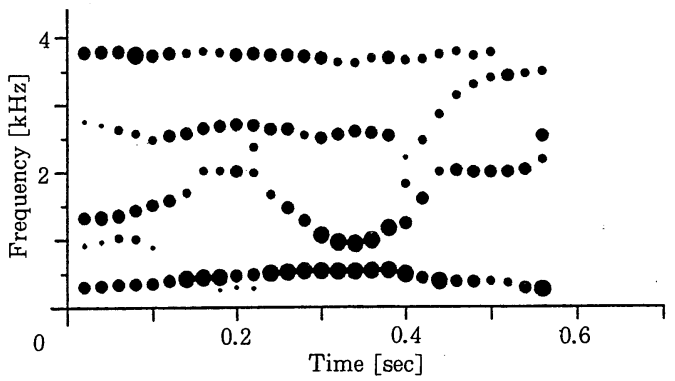

(b) Formant patterns of the separated voice

Fig. 6 An example of voice separation

ンを Fig. 4〜6 亿示す. Fig. 4 6の (a) は音源, (b) はその音源に対応する分離音声のホルマントパターンで ある. 各図の横軸は時間, 縦軸は周波数, ドットの大き さはホルマントの明瞭度を示す. 分離音声のホルマント パターンでは, 原音声に近いパターンが再生されている. また, 音源が正確に推定できた第 2 音のみならず, 第 1 , 第 3 音においてあホルマントパターンの特徴が再生され ており, 距離推定に誤差があってあ音声分離が可能であ るといえる.

\section{6.あとがき}

三つのマイクロフォンによる 3 次元 3 音源定位法につ いて理論的考察を行い，ての手法の有効性をシミュレー ションにより確かめた. また 2 次元空間における音声分 離では, 表面に現れなかった問題点に対処する必要があ るととを示した，すなわち，音源定位においては各マイ ク対から得られるデー夕間の対応関係を確認する必要が ある. てれについて本論文では, データのヒストグラム の極大点について対応関係を調べる方法をとった. 一方, 音声分離に扔いては，逆伝達関数が不安定極をあつ場合 が 2 次元の場合に比べて頻繁に生じる. ての問題につい ては極の再配置による安定化が有効であることを示した。 今後は現実の音環境に掞いて実験を行う必要がある. また，てのような方法でマイクを增加していった場合， 
どの程度の音源まで弁別可能か, またマイクアレイによ る音環境認識の可能性なよ゙, 今後研究する課題は多い.

\section{参 考 文 献}

1) 北守，原田，河原田：混合音声聴き分けの聴神経パルス相 互相関モデル；電子情報通信学会論文誌, Vol. J 67-A, No. 3, pp. 182 189 (1984)

2) 黄, 大西, 杉江 : 生体に示唆を得た音源定位システムー反 響のある環境での単一音源定位一; 電子情報通信学会論文 誌, Vol. J 71-A, No. 10, pp.1780 1789 (1988)

3）柳田，久下, 角所 : 多点受音による話者分離; 電子情報通 信学会技報, Vol. EA 77-52, pp. 47〜 51 (1978)

4) M. Yanagida, Y. Miyoshi, Y. Nomura and O. Kakusho: Application of the Least-Square Method to Source Sound Separation in Multi-Source Enviornment; Acoustica, Vol. 57, No. 3, pp. 158〜167 (1985)

5) 森田, 沖本, 藤井 : 音響場推定法による複数話者の音声分 離；電子情報通信学会技報, Vol. EA 88-68, pp. 13〜20 (1989)

6) 森田：音響パラメータ探索法による複数話者の音声分離 ; 電子情報通信学会論文誌, Vol. J 73-A, No. 10, pp.1551～ 1557 (1990)

7) 森田: 最小自乗推定法による音声分離の改善 ; 計測自動制 御学会学術講演会, Vol. JS 27-2, pp. 299 300 (1991) 